\title{
Incidence and Predictors of Early Recurrent Ischemia After Successful Percutaneous Transluminal Coronary Angioplasty for Acute Myocardial Infarction
}

Stephen G. Ellis, MD, Lynne Gallison, PA-C, Cindy L. Grines, MD, Alan B. Langburd, MD, Eric R. Bates, MD, Joseph A. Walton, Jr., MD, William W. O'Neill, MD, and Eric J. Topol, MD

Two hundred forty consecutive patients with acute myocardial infarction treated within $\mathbf{4 8}$ hours by successful percutaneous transluminal coronary angioplasty (PTCA) were analyzed to determine the incidence and predictors of recurrent ischemic events during hospitalization. Thirty-nine patients had recurrent ischemia: 20 patients had chest pain or electrocardiographic changes requiring repeat PTCA or bypass surgery, or resulting in a second creatine kinase elevation suggestive of myocardial infarction; 12 had total occlusion of the dillated artery on follow-up angiography; and 7 had exerciseinduced ischemia and $\geq \mathbf{7 0} \%$ diameter stenosis that required PTCA or bypass surgery before hospital discharge. In-hospital mortality was $15 \%$ in the recurrent ischemia group, compared to $1 \%$ in the group without recurrent myocardial ischemia (p $<0.001$ ). Angiographic follow-up before hospital discharge was obtained in 198 patients, including 38 of the 39 patients with ischemic events. Thus, the true incidence of recurrent ischemic events was between 39 of 199 and 39 of 240, or 16 and $20 \%$. In multivariate analyses, recurrent ischemia was predicted by translesional gradient $>25 \mathrm{~mm} \mathrm{Hg}$ (p $=0.001$ ), dissection $(p=0.01)$ and post-PTCA Thrombolysis in Myocardial Infarction 2 flow pattern $(p=0.016)$. However, even in the absence of these risk factors recurrent ischemic events occurred in $13 \%$ of patients. Post-PTCA percent diameter stenosis (whether assessed by objective or visual assessment), degree of the early systemic fibrinolytic state, post-PTCA residual minimal diameter and concomitant use of thrombolytic agents were not predictive. Thus, recurrent ischemia after successful PTCA for acute myocardial infarction occurs in 16 to $20 \%$ of patients, is significantly more common with post-PTCA translesional gradient $\geq 25 \mathrm{~mm} \mathrm{Hg}$, dissection or Thrombolysis in Myocardial Infarction 2 flow, but may also occur unpredictably.

(Am J Cardiol 1989;63:263-268)
$\mathrm{P}$ ercutaneous transluminal coronary angioplasty (PTCA), whether performed as primary therapy for patients with contraindication to thrombolysis or as an adjunct to failed thrombolytic therapy, can restore artery patency in 83 to $93 \%$ of patients with acute myocardial infarction (AMI). ${ }^{1-5}$ However, recurrent ischemia before hospital discharge has been reported in 5 to $31 \%$ of these patients. $3,4,6,7$ The predictors of recurrent ischemic events have not been described except in small series of patients. ${ }^{1,8-11}$ To define a successful PTCA result, and to assist in the anticipation of recurrent myocardial ischemia in selected patients, we retrospectively analyzed the in-hospital course of 240 consecutive patients who had AMI treated with successful PTCA for the correlates of recurrent myocardial ischemic events.

\section{METHODS}

Patients: All patients with AMI treated within 48 hours by PTCA at the University of Michigan from January 1985 until December 1986 with final percent stenosis of $<70 \%$ by quantitative coronary arteriography and final Thrombolysis in Myocardial Infarction flow grade $\geq 2^{12}$ were considered for this analysis. We used this broad and previously used ${ }^{3}$ definition of success to provide a spectrum of results so that a functional definition of success might be determined. We were also aware of concern that previous reports using visual estimation of percent stenosis may have overestimated the degree of artery opening after PTCA. Patients were excluded only if the procedural cineangiograms were unavailable for review $(n=31)$, or if the pre- or postdilatation cineangiogram was of insufficient quality to allow for quantitative analysis (usually because the angiographic guidewire was still placed across the lesion at

From the Division of Cardiology, Department of Internal Medicine, The University of Michigan Medical Center, Ann Arbor, Michigan. Manuscript recieved June 13, 1988; revised manuscript received October 6, 1988, and accepted October 9 .

Address for reprints: Stephen G. Ellis, MD, University of Michigan Medical Center, Cardiology Division, UH B1F245, 1500 East Medical Center Drive, Ann Arbor, Michigan 48109-0022. 


\section{ISCHEMIA AFTER ANGIOPLASTY FOR ACUTE MYOCARDIAL INFARCTION}

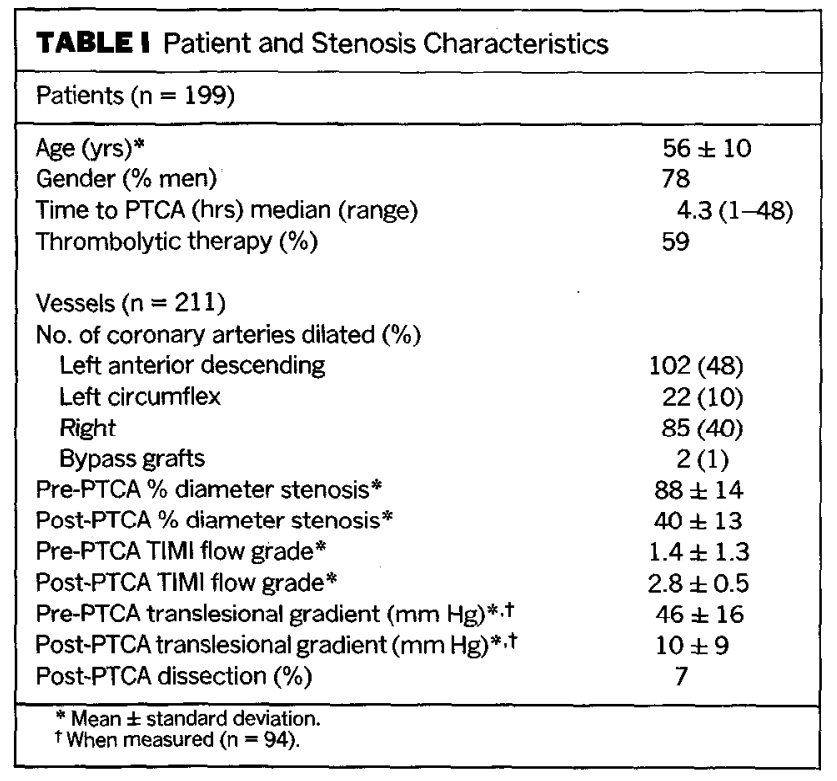

the time of the final cineangiogram) $(n=11)$. Based on in-hospital mortality, incidence of emergency bypass surgery and clinical characteristics, there was no bias of ascertainment induced by nonavailability or inadequate quality of cineangiograms. Eighty-two of these patients participated in previously reported ${ }^{4,5}$ or ongoing randomized trials assessing interventions in AMI. Thus, based on randomization, 74 patients also received intravenous recombinant tissue plasminogen activator (150 $\mathrm{mg}$ over 6 to 8 hours) before PTCA, and 8 patients received recombinant tissue plasminogen activator and urokinase ( 0.5 to 1.0 million U over 60 minutes) before PTCA. In addition, 49 patients received intravenous streptokinase (1.0 to 1.5 million U over 30 to $60 \mathrm{~min}$ utes) based on clinical indications before PTCA.

In all patients, PTCA was performed under guidelines approved by this institute's Committee to Review Grants for Clinical Research and Investigation Involving Human Beings. Informed consent was obtained from every patient before PTCA.

Indications: Two hundred twenty-four patients underwent clinically indicated PTCA on the basis of continued ischemic chest, neck or arm discomfort or persistent ST-segment elevation, and 16 patients were randomized to coronary angioplasty after apparently successful thrombolysis without apparent ongoing ischemia. Patients were not considered for PTCA in the presence of left main stenosis $\geq 60 \%$, or $\geq 70 \%$ diameter stenoses of both the proximal left anterior descending and the left circumflex coronary arteries, or for distal occlusions in tortuous vessels not felt to be technically suitable for the procedure. Patients were not necessarily excluded because of advanced age or poor left ventricular function, but often had primary angioplasty in this instance because they were excluded from randomized trials 4,5 using thrombolytic agents.

Angioplasty technique: The technique of PTCA used has been previously described. ${ }^{2}$ After angioplasty, patients were treated with intravenous heparin for 2 to 10 days, oral aspirin 80 to $600 \mathrm{mg}$ daily, dipyridamole
$225 \mathrm{mg}$ daily and oral calcium antagonists and nitrates as tolerated. Ninety-five patients were also given an infusion of low molecular weight dextran $(40 \mathrm{ml} / \mathrm{hr})$ for 24 hours. The vascular sheaths were usually left in place for 24 hours, at which time if the patient was clinically stable, the heparin was stopped for 2 to 3 hours and the sheaths wcre removed. After hemostasis had been achieved at the groin puncture site, the heparin infusion was resumed. All patients were initially monitored in the intensive care unit. Hemodynamic monitoring was performed and adjunctive drug therapy was administered as clinically indicated.

Data review: Clinical and procedural data were prospectively entered on case report forms at the time of catheterization. These forms and patient charts were audited by an observer unaware of the quantitative angiographic outcome to assure the completeness and accuracy of the data. Thirteen clinical variables were recorded: patient age, gender, history of diabetes mellitus, prior AMI location (anterior or inferior/posterior), prior use of $\beta$ blockers, prior use of calcium antagonists, time from onset of chest pain to initiation of coronary angioplasty, prior use of intravenous thrombolytic agents, systolic blood pressure on arrival in the cardiac catheterization laboratory, dextran use, nadir fibrinogen and peak fibrin split products after treatment.

Angiographic analysis: Quantitative measurements of the pre- and post-PTCA percent diameter stenosis and the absolute residual minimum diameter after angioplasty were performed using a previously described and validated automated quantitative system ${ }^{13}$ by an experienced angiographer blinded to clinical outcome. Pre- and post-PTCA percent stenosis and residual minimal diameters were reported as mean values from orthogonal projections. Visual assessment of percent diameter stenosis as assessed during clinical cineangiogram review was also recorded.

Contrast ventriculograms were analyzed for global left ventricular ejection fraction by the area-length method (CLC version 6A, VVF analysis, Electronics for Medicine). End-diastolic and end-systolic frames were selected by a blinded observer and the endocardial borders were digitized with the use of a lightpen system. ${ }^{14}$

In addition, pre- and post-PTCA infarct arteries were assessed by a blinded observer for Thrombolysis in Myocardial Infarction flow ${ }^{12}$ and 16 other previously defined angiographic or morphologic variables ${ }^{15}$ : artery dilated, proximal or nonproximal stenosis location, number of diseased arteries ( $\geq 50 \%$ diameter stenosis), post-PTCA dissection (extraluminal opacity or curvilinear intraluminal filling defect extending beyond the anatomic limits of the stenosis dilated), post-PTCA tear, lesion length to the nearest $\mathrm{mm}$, location of the stenosis at an end-diastolic bend $\geq 45^{\circ}$, branch point location, other stenoses $\geq 50 \%$ in the artery dilated, the presence of contrast staining or a filling defect in the pre- and post-PTCA films suggestive of thrombus, collaterals beyond the site dilated, diffuse disease in the artery dilated, calcification in the area of the stenosis dilated, stenosis eccentricity and intermittent arterial patency during the angioplasty procedure. 


\begin{tabular}{|llll|}
\hline \multicolumn{4}{|c|}{ TABLE II Clinical Consequences of Recurrent Ischemia } \\
\hline & $\begin{array}{l}\text { Recurrent } \\
\text { Ischemic } \\
\text { Events }(\mathrm{n}=39)\end{array}$ & $\begin{array}{l}\text { No Recurrent } \\
\text { Ischemic } \\
\text { Events }(\mathrm{n}=160)\end{array}$ & $\mathrm{p}$ Value \\
\hline Outcome & $20(51)$ & $0(0)$ & 0.001 \\
\hline $\begin{array}{l}\text { Emergency PTCA } \\
\text { Emergency bypass } \\
\text { surgery (\%) }\end{array}$ & $5(13)$ & $0(0)$ & 0.001 \\
In-hospital death (\%) & $6(15)$ & $2(1)$ & 0.001 \\
\hline
\end{tabular}

Recurrent ischemic events: Recurrent ischemic events were defined as the in-hospital occurrence of any of the following: recurrent chest pain or electrocardiographic changes requiring repeat PTCA or bypass surgery, or resulting in a second creatinine kinase elevation suggestive of a myocardial infarction: total occlusion of the artery dilated noted on follow-up angiography; and exercise-induced ischemia and a $\geq 70 \%$ diameter stenosis at the dilated site that required PTCA or bypass surgery before hospital discharge.

Statistical analysis: All data were entered into a relational database using a SYSTAT software package (SYSTAT, Inc.).

Unpaired Student's $t$ tests and chi-square analyses were used to compare continuous and categorical single variables with outcome. Multiple stepwise linear regression analyses with alpha to enter and remove equals $0.15^{16}$ were used to test hypotheses regarding the independent effect of variables on outcome. This was performed 3 times: first, using all patients with ischemia or angiographic follow-up; second, using only patients in whom the post-PTCA translesional gradient had been measured; and third, separating patients by type of adjunctive thrombolytic therapy received. A 2-tailed $p$ value $\leq 0.05$ was considered significant although values of $0.05<\mathrm{p} \leq 0.15$ are included for completeness. ${ }^{17}$

\section{RESULTS}

Patient and stenosis characteristics: The 240 patients had dilatations performed at 254 arterial sites (Table I). One-hundred ninety-eight patients were restudied by arteriography before hospital discharge, and 1 patient with only 1 site dilated had recurrent ischemia without catheterization. Table I shows the characteristics of the patients (and stenoses) who had either recurrent ischemia or angiographically documented vessel patency before discharge and thus comprise the study population. In addition to the data presented in Table I, there were $90(43 \%)$ total occlusions, calcium was visible in $12 \%$ of stenoses and collaterals beyond the site dilated had been visualized in $32 \%$. In the stenoses in which it could be assessed, $22 \%$ of dilatations were performed at bend points and $28 \%$ of dilatations were performed at branch points. The mean lesion length of the stenoses dilated was $2.9 \pm 3.6 \mathrm{~mm}$. Post-PTCA thrombus was present after 53 dilatations (24\%) with a mean length, when present, of $2.8 \pm 6.4 \mathrm{~mm}$. Other stenoses $\geq 50 \%$ in the same artery were present in $19 \%$ of the vessels dilated.

Incidence, timing and consequences of recurrent ischemic evenis: Twenty instances of overt clinical ische-

\begin{tabular}{|lllll|}
\hline \multicolumn{5}{|c|}{ TABLE III Selected Univariate Correlates of Ischemic } \\
Events*
\end{tabular}

mia occurred at $25 \pm 17$ hours after PTCA (Table II). Nineteen patients had stenoses of $\geq 70 \%$ documented angiographically and 1 patient with overt ischemia was not restudied (Table II). At the 5 to 10-day follow-up, 12 patients had total occlusion and 7 patients had stenoses $\geq 70 \%$ that were treated with PTCA or bypass surgery during the hospitalization because of exercise-induced ischemia. Forty-two patients without overt ischemia did not undergo follow-up angiography. Thus, the true incidence of recurrent ischemic events on a per patient basis was between 39 of 199 and 39 of 240 , or 16 and $20 \%$.

As shown in Table II, patients with recurrent ischemia had more repeat PTCAs, more emergency bypass surgery and a higher mortality during hospitalization. Of patients with recurrent ischemia, 20 had repeat PTCA (15 successful), 5 had emergency bypass surgery and 4 had elective bypass surgery. There were 6 deaths in this group (mortality rate $15 \%$ ).

Univariate predictors of recurrent ischemic events: When all patients with follow-up were considered, 3 variables were significantly correlated with the recurrent ischemic events in the univariate analyses: postPTC $\Lambda$ Thrombolysis in Myocardial Infarction flow grade $2(p=0.03)$, dissection $(p=0.04)$ and postPTCA gradient $\geq 25 \mathrm{~mm} \mathrm{Hg}(\mathrm{p}=0.05)$. Post-PTCA percent stenosis, measured either using quantitative coronary arteriography or visually, post-PTCA minimum 
diameter, post-PTCA gradient $\geq 20 \mathrm{~mm} \mathrm{Hg}$, pre-PTCA thrombus and all other variables were not related to recurrent ischemic events (Table III).

Restricting the analysis to stenoses with orthogonally measured percent stenosis and residual minimum diameter $(n=114)$ did not improve the predictive value of either variable for recurrent ischemic events (percent stenosis in all patients: $\mathrm{t}=0.68, \mathrm{p}=0.49$; orthogonally viewed stenoses only, $\mathrm{t}=0.30, \mathrm{p}=0.77$; residual minimal diameter, all patients, $\mathrm{t}=-0.06, \mathrm{p}=0.95$; orthogonally viewed stenoses, $t=0.12, p=0.90$ ). Objective assessment of post-PTCA stenosis severity consistently found pre-PTCA percent stenosis lower $(88 \pm 14$ vs 94 $\pm 9, \mathrm{p} \leq 0.001)$ and post-PTCA percent stenosis higher $(40 \pm 13$ vs $31 \pm 14, p \leq 0.001)$ than visual assessment, but neither assessment of stenosis severity was a strong predictor of recurrent ischemic events.

There was no significant difference in the incidence of recurrent ischemic cvents between patients treated with long-acting, systemic, fibrinolytic agents (streptokinase or urokinase) (13 of $67,19 \%)$, short half-life, "clot-selective" fibrinolytic agents (tissue plasminogen activator) $(16$ of $58,28 \%)$ or no fibrinolytic agents at all $(10$ of $66,15 \%)$ (chi-square $=3.0, p=0.22$ ).

Multivariate predictors of recurrent ischemic events: When all sites were analyzed, Thrombolysis in Myocardial. Infarction flow grade 2 (coefficient $=$ $0.028, \mathrm{p}=0.001$ ) and dissection (coefficient $=0.26, \mathrm{p}$ $=0.01$ ) were found to be independently correlated with recurrent ischemic events (constant $=0.14$ ). When only sites with gradients available were analyzed, a gradient $\geq 25 \mathrm{~mm} \mathrm{Hg}$ was also found to be a significant correlate of recurrent ischemic events (coefficient $=0.60, \mathrm{p}=$ 0.001).

For patients not receiving thrombolytic therapy, post-PTCA dissection (coefficient $=0.38, p=0.002$ ), post-PTCA Thrombolysis in Myocardial Infarction flow 2 (coefficient $=0.32, \mathrm{p}=0.003$ ), and gradient $\geq 25$ $\mathrm{mm} \mathrm{Hg}$ (coefficient $=0.93, \mathrm{p}=0.001$ ) predicted recurrent ischemia with a constant of 0.12 . For patients treated with either intravenous streptokinase or urokinase, post-PTCA thrombus (coefficient $=0.37, \mathrm{p}=$ 0.03 ) and post-PTCA Thrombolysis in Myocardial Infarction flow 2 (coefficient $=0.39, p=0.04$ ) predicted recurrent ischemia with a constant of 0.27 . For patients treated with intravenous tissue plasminogen activator, pre-PTCA Thrombolysis in Myocardial Infarction flow grade 2 predicted recurrent ischemia (coefficient = $0.25, \mathrm{p}=0.03$ ) with a constant of 0.09 . Within the high risk group (Thrombolysis in Myocardial Infarction flow grade 2 ), only a gradient $\geq 25 \mathrm{~mm} \mathrm{Hg}$ was a predictor of recurrent ischemic events $(p=0.006)$.

\section{DISCUSSION}

PTCA performed in the setting of AMI can restore arterial patency with efficacy similar to that of the best currently available thrombolytic agents, ${ }^{4,12}$ but recurrent ischemia after angioplasty, as with thrombolytic therapy alone,,$^{2,4,18-20}$ is not uncommon..$^{3,4,6,9-11}$ Recent studies suggest that PTCA need not be performed immediately after successful thrombolysis, ${ }^{4}$ but PTCA may be beneficial for patients who fail or have contraindications to thrombolytic therapy, or who have early recurrent ischemia after initially successful thrombolysis. $1,2,6$

To determine the incidence and the predictors of recurrent ischemic events after angioplasty, we analyzed 240 consecutively treated patients, 198 of whom had angiographic follow-up 5 to 10 days after PTCA or at the time of ischemia. The incidence of recurrent ischemic events on a per patient basis was between 16 and $20 \%$, and in-hospital mortality was higher in these patients than in those without recurrent ischemic events ( 15 vs $1 \%$, p <0.001).

The predictors of recurrent ischemic events after PTCA in this setting have not been evaluated in a comprehensive manner using quantitative arteriography. Simari et $\mathrm{a}^{10}$ analyzed 142 patients trcated in this setting but they did not use quantitative arteriography. Early reocclusion occurred in $13 \%$ of patients, and was independently correlated with time to PTCA $>4$ hours, prePTCA thrombus, post-PTCA dissection, patient age, post PTCA Thrombolysis in Myocardial Infarction flow grade, left anterior descending or right coronary PTCA and "irregular borders" after PTCA.10 In smaller series of patients, but using quantitative techniques, Dean et $\mathrm{al}^{9}$ found reocclusion to be related to post-PTCA diameter stenosis and Thrombolysis in Myocardial Infarction flow grade. Grines et $a^{11}$ found that post-PTCA diameter stenosis $>50 \%$ predicted either recurrent ischemia or an abnormal early exercise test result. Neither of these smaller series used multivariate testing.

In this study, 3 of the 34 variables tested were independently correlated with recurrent ischemic events: post-PTCA Thrombolysis in Myocardial Infarction flow 2 , post-PTCA dissection and post-PTCA translesional pressure gradient $\geq 25 \mathrm{~mm} \mathrm{Hg}$. However, recurrent ischemic events still occurred in $13 \%$ of patients without these risk factors, and were not predictable by any prePTCA findings.

After thrombolytic therapy alone, without the additional vessel injury induced by PTCA, residual minimal diameter and percent diameter stenosis have been suggested as the best predictors of adverse outcome. ${ }^{18-20}$ Residual lumen dimension does not appear to be a good risk predictor after thrombolysis with tissue plasminogen activator. ${ }^{21}$ These factors were not found to be predictive in this study. Discordance between flow and quantitatively measured percent diameter or area stenosis in the nontraumatized but diseased coronary artery is well recognized. ${ }^{22}$ The correlation with flow and residual minimal diameter is better. ${ }^{22}$ However, in situ thrombus and trauma induced by balloon dilatation may impair definition of vessel edges; ${ }^{23}$ further, PTCA may lead to vasoconstriction of adjacent coronary sites. $^{24}$ All of these factors might potentially decrease the utility of percent stenosis or residual minimal diameter to predict outcome. It is not surprising that poor 
flow, which may indicate a poor PTCA result or high distal resistance from the "no reflow phenomenon," 25 may be a better predictor of subsequent ischemia.

Dissection and high translesional gradients have previously been reported as the most important procedural predictors of acute complications after elective coronary angioplasty, ${ }^{15}$ hence their importance in the setting of AMI is not unexpected. Dissection, aside from potentially compromising flow, is a potent stimulus for thrombus formation. 26,27

Limitations: There are 3 potential limitations to this study. First, the post-PTCA result was not viewed in orthogonal projections in all patients. Measured percent diameter stenosis in the right anterior oblique and left anterior oblique projections correlated very well in Nichols' study of 10 diagnostic angiograms $(r=0.99)^{28}$ but correlated poorly in Sanz's analysis of 13 vessels that had undergone PTCA $(r=0.07) .{ }^{23}$ However, limiting this analysis to patients with orthogonally viewed stenoses did not improve the poor correlation between percent stenosis or residual minimal diameter and recurrent ischemic events. Second, post-PTCA translesional gradients were not recorded in all patients, and clinical judgment may not always exclude "falsely" elevated gradients, as can be seen with large balloon/artery ratios, vasospasm or intermittent thrombus formation. ${ }^{29}$ Finally, the influence of the completeness of patient anticoagulation on recurrent ischemia could not be assessed. All patients were given antiplatelet agents and heparin after PTCA, but activated partial thromboplastin times temporally proximate ( $<4$ hours) to the time of recurrent ischemia were available for only a small minority of patients.

Implications: Recurrent ischemic events after successful PTCA for AMI are not uncommon, are not always predictable and have definite serious adverse consequences. Close patient monitoring and immediate catheterization and surgical availability, especially during the first 24 to 48 hours after PTCA when the risk is highest, are mandatory. Patients who have diminished coronary flow, high translesional gradient or dissection after PTCA, especially if there is a large amount of potentially viable myocardium at risk, should be considered for emergency bypass surgery, and PTCA should not be considered complete until an attempt at reducing the translesional gradient to $<25 \mathrm{~mm} \mathrm{Hg}$ has been made. Finally, improved techniques for maintaining artery patency, such as intracoronary stenting ${ }^{30}$ or antiplatelet antibodies, ${ }^{31}$ are needed.

Acknowledgment: The authors wish to extend particular appreciation to Sheree Wilson and Vanessa J. Sims for preparation of this manuscript.

\section{REFERENCES}

8. Hartaler GO, Rutherford BD, McConahay DR, Johnson WL, McCaliester BD, Gura GM, Conn RC, Crockett JE. Percutaneous transluminal coronary angioplasty with and without thrombolytic therapy for treatment of acute myocardial infarction. Am Heart 1 1983:106:965-973.
2. O'Neill WO, Timmis GC, Bourdillon PD, Lai P, Ganghadarhan V, Walton J, Ramos R, Laufer N, Gordon S, Schork A, Pitt B. A prospective randomized linical trial of intracoronary streptokinase versus coronary angioplasty for acute myocardial infarction. $N$ Engl $J$ Med 1986;314:812-818.

3. Rothbaum DA, Linnemeier TJ, Landin RJ, Steinmetz EF, Hillis JS, Hallam CC, Nuble J, See MR. Einergency perculaneuus transtuminal coronary angioplasty in acute myocardial infarction: a three year experience. JACC 1987 10:264-272,

4. Topol EJ, Califf RM, George BS, Kereiakes DJ, Abbottsmith CW, Candela RJ, Lee KL, Pitt B, Stack RS, O'Neill WW, and the Thrombolysis and Angioplasty in Myocardial Infarction Study Group. A randomized trial of immediate versus delayed elective angioplasty after intravenous tissue plasminogen activator in acute myocardial infarction. $N$ Engl J Med 1987;317:581-588.

5. Topol EJ, Califf RM, George BS, Kereiakes DJ, Lee K, Rothbaum D, Candela RJ, Abbottsmith CW, Pinkerton CA, Stump D, Collen D, Pitt B, Kline E, Boswick J, O'Neill W, Stack R, and the 'TAMI Study Group. Coronary arterial thrombolysis with combined infusion of recombinant tissue-type plasminogen activator and urokinase in patients with acute myocardial infarction. Circulation 1988,77:1100-1107.

6. Stack RS, O'Connor C, Mark D, Hinohara T, Phillips H, Lec M, Ramirez N, O'Callaghan W, Simonton C, Carlson E, Morris K, Behar V, Kong V, Peter R, Califf RM. Coronary perfusion during acute myocardial infarction with a combined therapy of coronary angioplasty and high dose intravenous streptokinase. Circulation 1988.77:151-161.

7. Chesebro JH, Knatterud G, Roberts R, Borer J, Cohen LS, Dalen J, Dodge HT, Francis CK, Hillis D, Ludbrook P, Markis JE, Mueller H, Passamani ER, Powers ER, Rao AK, Robertson T, Ros A, Ryan TJ, Sobel BE, Willerson J, Williams DO, Zaret BL, Braunwald E. Thrombolysis in Myocardial Infarction

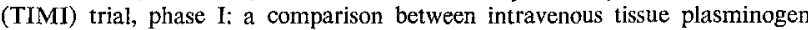
activator and intravenous streptokinase. Clinical findings through hospital discharge. Circulation 1987,76:142-154

8. Papapictro SE, MacLean WH, Stanley $\Lambda \mathrm{H}$, Hess RG, Corley N, Arciniegas JG, Cooper TB. Percutaneous transluminal coronary angioplasty after intracoronary streptokinase in evolving acute myocardial infarction. $\mathrm{Am} J \mathrm{Cardiol}$ 1985:55:48-53.

9. Dean EN, Langburd AB, Topol EJ, O'Neill WW. Early re-occlusion following angioplasty for the treatment of acute myocardial infarction. Circulation 1986,74(suppl II $): I I-24$.

10. Simari RD, Rutherford BD, Ligon RW, Giorgi LV, Osborn JS, McConahay DR, Hartzlerg O, Johnson WL, McCallister BD. PTCA in acute myocardial infarction: a multivariate analysis of predictors of early reocclusion. Circulation 1986,74(suppl II):24.

11. Grines CL, Topol EJ, Bates ER, Bourdillon PDV, Walton JA, Pitt B. Residual stenosis of infarct vessel after intravenous tissue plasminogen activator and acute angioplasty predicts clinical outcome. Circulation 1986,74(suppl II) 277

12. TIMI Study Group. The thrombolysis and myocardial infarction (TIMI) trial: phase I findings. $N$ Engl J Med 1985;312:932-936.

13. Mancini GBJ, Simon SB, McGillem MJ, LeFree MT, Friedman HZ, Vogel RA. Automated quantitative coronary arteriography: morphologic and physiologic validation in vivo of a rapid digital angiographic method. Circulation 1987,75:452-460.

14. Hodgson JM, O'Neill WW, Laufer N, Bourdillon PDV, Walton JA, Pitt B. Assessment of potentially salvageable myocardium during acute myocardial infarction: usc of postextrasystolic potentiation. Am J Cardiol 1984;54:1237-1244. 15. Ellis SG, Roubin GS, King SB, Douglas JS, Weintraub WS, Thomas RG, Cox WR. Angiographic and clinical predictors of acute closure after native vessel coronary angioplasty. Cirrulation 1988:77:372-379.

16. Bendel RB, Afifi AA. Comparison of stopping rules and forward "stepwise" regression. J Am Statistical Assoc 1977;72:46-53.

17. Pocock SJ, Hughes MD, Lee RJ. Statistical problems in the reporting of clinical trials. A survey of three medical journals. $N$ Engl J Med 1987;317:426432.

18. Serruys PW, Wijns W, VanDenBrand M, Rebeiro V, Fioretti P, Simoons ML, Kooijmanc J, Reiber JHC, Hugenholtz PG. Is transluminal coronary angioplasty mandatory after successful thrombolysis? Quantitative coronary angiographic study. Br Heart $J$ 1983;50:257-265.

19. Gold HK, Leinbach RC, Palacios IF, Yasuda T, Block PC, Buckley MJ, Akins CW, Daggett WM, Austen WG. Coronary reocclusion after selective administration of streptokinase. Circulation 1983,68( suppl n):I-50.

20. Harrison DG, Furguson DW, Collins SM, Skorton DJ, Ericksen EE, Kioschos JM, Marcus ML, White CW. Rethrombosis after reperfusion with streptoki nase: importance of geometry of residual lesions. Circulation 1984,69:991-999. 21. Ellis SG, Topol E, Debowey D, Stack R, O'Neill W, Boswick J, George B, Kereiakes D, Abbottsmith C, Candela R, Califf RM and the TAMI Study group. Recurrent ischemia without warning: inability to predict ischemic events from residual stenosis after successful coronary thrombolysis (abstr). JACC 1988; 11:105A.

22. Harrison DG, White CW, Hiratzka LF, Doty DB, Barnes DH, Eastham CL Marcus ML. The value of lesion cross-sectional area determined by quantitative coronary angiography in assessing the physiolngic significance of proximal left 


\section{ISCHEMIA AFTER ANGIOPLASTY FOR ACUTE MYOCARDIAL INFARCTION}

anterior descending coronary arterial stenoses. Circulation 1984;69:1111-1119. 23. Sanz ML, Mancini GBJ, LeFree MT, Mickelson JK, Starling M, Vogel RA Topol EJ. Variability of quantitative digital subtraction coronary angiography before and after percutaneous transluminal coronary angioplasty. Am J Cardio 1987;60:55-60.

24. Lain JYT, Chcsebro JH, Steele PM, Badimon L, Fuster V. Is vasospasm related to platelet deposition? Relationship in a porcine preparation of arteria injury in vivo. Circulation 1987:75:243-248.

25. Kloner RA, Ganote CF, Jennings RB. The "no-reflow" phenomenon after temporary coronary occlusion in the dog. Circulation 1974;54:1494-1499.

26. Wilentz JR, Sanborn TA, Haudenschild CC, Valeri CR, Ryan TJ, Faxon

DP. Platelet accumulation in experimental angioplasty: time course in relation to vascular injury. Circulation 1987,75:636-642.

27. Bates ER, McGillem MJ, Beals TF, DeBoe SF, Mickelson JK, Mancini GBJ, Vogel RA. Effect of angioplasty-induced endothelial denudation compared with medial injury on regional coronary blood flow. Circulation 1987,76:710-716. 28. Nichols AB, Gabrieli CF, Fenoglio JJ, Esser PD. Quantification of relative coronary artery stenosis by cinevideodensitometric analysis of coronary angiograms. Circulation 1984,69:512-522.

29. Ganz P, Abben R, Friedman PL, Garnic JD, Barry WH, Levin DC. Usefulness of transstenotic coronary pressure gradient measurements during diagnostic catheterization. Am J Cardiol 1985,55:910-914.

30. Sigwart U, Puel J, Mirkovitch V, Joffre F, Kappenberger L. Intravascular stents to prevent occlusion and restenosis after transluminal angioplasty. $N$ Engl.T Med 1987;316:701-707.

31. Gold HK, Coller B, Yasuda T, Saito T, Fallon J, Guerrero J, Leinbach R Ziskind AA, Collen D. Rapid and sustained coronary artery recanalization with combined bolus injection of recombinant tissue-type plasminogen activator and monoclonal anti platelet GPIIb/IIIa antibody in a canine preparation. Circulation 1988:77:670-677. 